\title{
NOTES
}

\section{INJUNCTIONS IN THE THREE-JUDGE DISTRICT COURTS: EQUITABLE ABSTENTION}

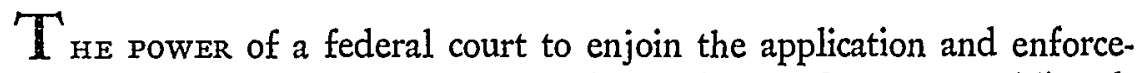
ment of state law ${ }^{1}$ was not fully settled until i908. ${ }^{2}$ Once established, however, it soon became apparent that the invocation of this equitable power was incompatible with state autonomy in certain important respects. $^{3}$ As a consequence, certain legislative limitations were quick to appear. A statutory three-judge court replaced the single district judge in suits invoking this particular type of injunctive relief.4 Further, lim-

\footnotetext{
1 The equity powers of the federal courts are derived from Article III, \$2, of the Federal Constitution. In Osborn v. Bank of the United States, 22 U.S. (9 Whent.) 738 ( 1824 ), the Supreme Court recognized federal jurisdiction to enjoin enforcement of unconstitutional state statutes, so long as the injunction could be analogized to the English chancery practice of enjoining acts beyond the scope of official authority. The Court held that a state officer possesses no official capacity when acting illegally and hence can derive no protection from an unconstitutional state statute. Thus it was reasoned that suits brought against state officials acting pursuant to an unconstitutional statute are suits against the officer in his individual capacity, and therefore are not prohibited by the eleventh amendment. Smyth v. Ames, I 69 U.S. 466 (I898). But of. Ex parte Young, 209 U.S. I23, I68 (1908) (dissenting opinion); Fitts v. McGhee, I72 U.S. 516 (1899); In re Ayers, 123 U.S. 443 (1887).

${ }^{2}$ Ex parte Young, 209 U.S. I23 (1908), established the rule that jurisdiction exists in the federal courts to restrain the enforcement of an unconstitutional state statute prior to a determination of its constitutionality in the state courts. In addition, the decision rejected the distinction drawn in Osborn v. Bank of the United States, 22 U.S. (9 Wheat.) 738 ( 1824$)$, ". . between a suit against individuals, holding official positions under a State, to prevent them, under the sanction of an unconstitutional statute, from committing by some positive act a wrong or trespass, and a suit against officcrs of a State merely to test the constitutionality of a state statute, in the enforcement of which those officers will act only by formal judicial proceedings in the courts of the State. ..." Fitts v. McGhee, I72 U.S. 516, 529-30 (1899).

${ }^{3}$ See generally, Frankfurter, Distribution of Judicial Power Between United States and State Courts, I 3 Cornell L.Q. 499 (rg28); Lockwood, Maw, and Rosenberry, The Use of the Federal Injunction in Constitutional Litigation, 43 HARV. L. REV. 426 (1930).

"Abuses by single federal judges in the issuance of ex parte restraining orders and interlocutory injunctions following $E x$ parte Young, 209 U.S. 123 (1908), prompted Congress to create three-judge federal district courts to hear applications for an interlocutory or permanent injunction restrainiug the enforcement of any state statute or administrative order on the ground that such state action violates the Federal Constitution. 36 STAT. II50, II62 (I9II), superceded by 62 STAT. 968 (1948), 28 U.S.C. $\$ \S 2281,2284$ (1952). A direct appeal to the Supreme Court was provided by 36
} 
ited immunity from federal injunction was accorded to state public utility rate orders ${ }^{5}$ and to state tax laws. ${ }^{6}$

Added to these congressional limitations were a variety of self-imposed judicial restraints which, when taken together, constitute the doctrine of "equitable abstention." Significant among these is the rule of the Prentis case, ${ }^{7}$ which postpones the availability of federal injunctive relief against state administrative action until the complainant has exhausted his nonjudical remedies. ${ }^{8}$ Also of significance is the rule that

STAT. II50, II62 (I9II), superceded by 62 STAT. 928 (I948), 28 U.S.C. § 1253 (1952). See, Hutcheson, $A$ Case for Three Judges, 47 HARv. L. REv. 795 (1934).

${ }^{5}$ The Johnson Act of 1934,62 STAT. 932 (1948), 28 U.S.C. $\S 1_{342}$ (1952), provided that federal district courts could not restrain the enforcement of state public utility rate orders, unless such orders interfere with interstate commerce, or are not made after reasonable notice and hearing, or the state courts afford no "plain, speedy and efficient" remedy. As to what constitutes a "plain, speedy and efficient" remedy in the state courts, see Corporation Commission of Oklahoma v. Cary, 296 U.S. 452 (1935); Prentis v. Atlantic Coast Line Co., 2 I I U.S. 2 Io (1908); Driscoll v. Edison Light \& Power Co., 307 U. S. I04 (1939); Mountain States Power Co. v. Public Service Commission of Montana, 299 U.S. 167 (1936). For discussions of state remedies and the observance of due process, see Notes, 44 YALE L.J. II9 (1934); 30 ILL. L. REv. 215 (1935); 35 Mich. L. REV. 274 (1936); 50 HARV. L. REv. 813 (1937).

${ }^{\circ}$ The Tax Injunction Act of 1937 , often referred to as an amendment to the Johnson Act, withheld federal district court jurisdiction to enjoin the assessment, levy or collection of state taxes where a "plain, speedy and efficient" remedy is available in the state courts. 62 STAT. 932 (1948), 28 U.S.C. § I 34 I (1952). This legislation was a codification of prior court decisions. See, Matthews v. Rodgers, 284 U.S. 521 (1932); Henrietta Mills v. Rutherford County, 28x U.S. 121 (1930). Formerly, one of the tests of the adequacy of the remedy in the state courts was the concurrent availability of a remedy in the federal courts. Southern Pacific Co. v. Gallagher, 306 U.S. I67 (1939); Forth Worth v. Southwestern Bell Telephone Co., 8o F.2d 972 (5th Cir. 1936). But in Norton v. Cass County, I 15 F.2d 884 ( 5 th Cir. 1940), it was held that the Tax Act had changed the test to a question of the existence of a remedy in the state courts at law or equity. Note, 59 HARv. L. REv. 780 (1946). In Great Lakes Dredge \& Dock Co. v. Huffman, 319 U.S. 293 ( 1943 ), involving an action for declaratory judgment as to the constitutionality of a state tax, federal relief was denied, since the taxpayer's right to sue for a refund after payment of a contested tax afforded an adequate remedy in the state courts. The Supreme Court refused to declare whether the Tax Injunction Act could be construed as prohibiting federal declaratory judgments, but was of the opinion that "... . those considerations which have led federal courts of equity to refuse to enjoin the collection of state taxes, save in exceptional cases, require a like restraint in the use of the declaratory judgment procedure." 319 U.S. at 299. See, Comment, 50 YALE L.J. 927 (I94I).

${ }^{7}$ Prentis v. Atlantic Coast Line Co., 2 II U.S. 2 10 (1908).

${ }^{8}$ Ibid. In a suit to enjoin a railroad rate order established by a state commission, an appeal was available to the highest state court endowed with legislative powers to change the rate order. As to the propriety of federal injunction prior to such legislative review, the Supreme Court held that federal judicial review must be postponed until all legislative remedies had been exhausted in the state courts. See Porter v. Investors Syndicate, 286 U.S. 46x (1932); Pacific Live Stock Co. v. Lewis, 24 I U.S. 440 
an equity court should hesitate to interfere with state criminal proceedings. ${ }^{9}$ Further, abstention is generally required when the problem concerns an area of state law so specialized as to be beyond the competence of federal judges. ${ }^{10}$

Not so well defined as these other limitations is an area of equitable

(19x6). The Prentis rationale has been judicially extended to include exhaustion of administrative remedies at the state level. Illmois Commerce Commission v. Thomson, 318 U.S. 675 (1943); Gilchrist v. Interborough Rapid Transit Co., 279 U.S. 159 (1929); First National Bank of Greeley v. Board of County Commissioners, 264 U.S. 450,454 (1924). However, where the complainant can invoke federal jurisdiction, he is not bound to pursue judicial review in the state courts. R.R. and Warehouse Commission v. Duluth Street Ry. Co., 273 U.S. 625 (1927); Prendergast v. New York Telephone Co., 262 U.S. 43 (1923). Also, where a state court acts legislatively, but provides no stay of an allegedly confiscatory rate order, the Prentis doctrine is inapplicable; and federal equity will intervene. Pacific Tel. \& Tel. Co. v. Kuykendall, 265 U.S. 196 (1924). See Driscoll v. Edison Light \& Power Co., 307 U.S. 104 (1939). Query: whether a state court could exercise both legislative and judicial powers in one adjudication-i.e., could the court affirm or modify the administrative rate order and then act judicially by passing upon the reasonableness of the rate order? Moreover, would the Supreme Court be exercising appellate jurisdiction in reviewing a case where the state court acted legislatively? See, Note, 3 I CoLum. L. Rev. 669 (1931).

${ }^{9}$ Generally, courts of equity will not restrain criminal proceedings. Hygrade Provision Co. v. Sherman, 266 U.S. 497, 500 (1925); Davis and Farnum Mfg. Co. v. Los Angeles, r 89 U.S. 207 (1903); In re Sawyer, 124 U.S. 200, 2 II (1888). However, "equitable jurisdiction exists to restrain criminal prosecutions under unconstitutional enactments, when the prevention of such prosecutions is essential to the safeguarding of rights of property" [Truax v. Raich, 239 U.S. 33, 37 (x915)] and the "rights of persons against injuries otherwise irremediable" [Terrace v. Thompson, 263 U.S. 197, $\left.2 I_{4}\left(I_{923}\right)\right]$. As regulatory measures are often couched in penal terms, the increase of interlocutory proceedings to restrain such action has prompted federal equity to apply more rigorous standards. Before equity will grant relief there must be a showing of irreparable injury "both great and immediate." Williams v. Miller, 317 U.S. 599 (1942); Spielman Motor Sales Co. v. Dodge, 295 U.S. 89, 95 (1935). Moreover, in Beal v. Missouri Pacific R.R., 312 U.S. 45 (194I), the Supreme Court withheld equitable relief, since the requirement that danger of irreparable loss must be "great and immediate" was not met, in that the controversy could be settled by a single prosecution in the state court. Where the criminal statute is challenged as invalid, the accused may incorporate that allegation as a defense to a prosecution in the state court, with ultimate review in the Supreme Court of federal questions. Fenner v. Boykin, 271 U.S. 240 (1926). See also, Douglas v. City of Jeannette, 319 U.S. 157,163 (I943).

${ }^{10}$ Judicial opinion varies as to whether it is an exercise of sound equitable discretion to abstain in all cases where the issue underlying the constitutional question is one of highly complicated local law. Alabama Public Service Commission v. Southern Ry. Co., 34I U.S. 34 I (I950), was a suit to enjoin a state commission from enforcing its ruling denying petitioners the right to discontinue two passenger trains. Allegedly, the order would result in confiscation of property in violation of the due process clause of the fourteenth amendment. The Supreme Court reversed the district court's grant of injunction on the grounds that intrastate railroad service regulation is "primarily the concern of the state," and that adequate judicial review was available in the state courts. The Court distinguished the cases in which jurisdiction had been withheld to avoid 
abstention which comes into focus only when injunction is sought against a state statute as violative of the Federal Constitution. ${ }^{11}$ Here, abstention is primarily rooted in the traditional judicial sentiment that decision of constitutional issues should be avoided whenever possible. ${ }^{12}$ This sentiment is intensified in these cases by the realization that a particularly sensitive area of federal-state relations is involved..$^{13}$ A questionable district court decision, now pending on appeal to the Supreme Court, raises the possibility that this problem area will presently receive definitive treatment.

In Doud v. Hodge, ${ }^{14}$ petitioners, regulated by the provisions of an Illinois act ${ }^{15}$ controlling those "engaged in the business of selling or

premature constitutional decision, and appeared to rely mainly upon principles of comity. Although Mr. Justice Frankfurter concurred in the result, believing that petitioner's bill should have been dismissed for failure to state a substantial claim under the Constitution, he vigorously protested the opinion of the Court as a "flagrant contradiction with an unbroken course of decisions in this Court for seventy-five years." $34 \mathrm{x}$ U.S. at 362 . Perhaps the fact that federal jurisdiction rested on diversity of citizenship in addition to a claim under the Constitution encouraged Mr. Justice Frankfurter in his protest. See Burford v. Oil Co., 319 U.S. 315,336 (1943) (dissenting opinion), wherein abstention in recognition of "basic problems of Texas policy" was weighed against diversity of citizenship (in addition to a constitutional claim) jurisdiction.

${ }^{21}$ Where federal equity jurisdiction can rest on grounds other than a federal constitutional question, the district court will not abstain merely because the state statute has not yet been construed. For example, in Meredith ซ. Winter Haven, 320 U.S. 228 (x943), claimant sought to restrain an allegedly unlawful retirement of municipal bonds. Jurisdiction was based on diversity of citizenship. In reversing a dismissal by the district court, the Supreme Court held that presence of uncertain state law was insufficient reason for deferring the cause to the state courts. Similarly, Propper v. Clark, 337 U.S. 472 (1948), involved an underlying issue of state law previously undetermined by the state supreme court. The Court held: "Where a case involves a nonconstitutional federal issue ... the necessity for deciding which depends upon the decision on an underlying issue of state law, the practice of federal courts has been, when necessary, to decide both issues." 337 U.S. at 490. See Estate of Spiegal v. Commissioner, 335 U.S. 701 (1949); Markham v. Allen, 326 U.S. 490 (1946).

22 "If there is one doctrine more deeply rooted than any other in the process of constitutional adjudication it is that we ought not to pass on questions of constitutionality ... unless such adjudication is unavoidable." Spector Motor Service, Inc. v. McLaughlin, 323 U.S. Ior, 105 (1944). See also Chicago v. Fieldcrest Dairies, 316 U.S. 168 (x942) ; R.R. Commission of Texas v. Pullman Co., 312 U.S. 496 (194I).

${ }^{23}$ "Few public interests have a higher claim upon the discretion of a federal chancellor than the avoidance of needless friction with state policies, whether the policy relates to the enforcement of the criminal law ... or the final authority of a state court to interpret doubtful regulatory laws of the state. ..." Railroad Commission of Texas v. Pullman Co., 312 U.S. 496, 500 (I94I) (citing cases).

14 127 F. Supp. 853 (N.D. I11. 1955), appeal docketed, No. 129, June 6, 1955, 24 U.S.L. WEEK 3004 (U.S. Jul. 5, I955).

${ }^{15}$ Illinois Community Currency Exchange Act, ILL. REv. STAT., c. $16 \pm / 2, \$ \S 30$ to 56.3 (1953). 


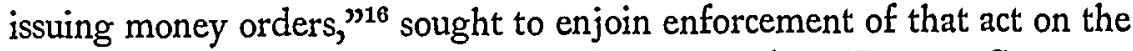
ground that its explicit exemption of the American Express Company was highly discriminatory and violative of the fourteenth amendment. ${ }^{17}$ In dismissing the bill for want of jurisdiction, a three-judge federal district court held that it could not entertain the cause, absent an authoritative determination by the Illinois Supreme Court as to the constitutionality of the statute. ${ }^{1 s}$

For purposes of analysis, it should be observed that when a federal district court abstains from passing on the constitutionality of a state statute, it awaits one of three possible results. First, the federal constitutional issue might be averted by a narrow state court construction of the statute. Second, the state court might declare the statute constitutional, in which case the complainant would have available an appeal to the United States Supreme Court. And finally, the state court, may, itself, declare the statute violative of the Federal Constitution.

When the first of these possible results of state litigation can be anticipated, equitable abstention would seem to be not only proper, but quite desirable. ${ }^{19}$ By proceeding on the assumption that the state courts will give the statute a narrow, constitutional construction, the federal courts can spare themselves the possible embarrassment of having to announce an altogether tentative decision. ${ }^{20}$ However, this assumption

${ }^{16} I d$. at $\S 31$.

${ }^{17}$ U.S. CoNST. amend XIV, § 1 .

${ }^{18}$ Plaintiffs had relied on Currency Services, Inc. v. Matthews, 90 F. Supp. 40 (W.D. Wis. 1950), wherein a district court enjoined enforcement of a Wisconsin statute, modeled after the Illinois Community Currency Exchange Act, on the grounds that it contravened the equal protection clause of the fourteenth amendment. But the district court opined that plaintiffs could make a plausible argument to the Illinois Supreme Court, ". . . predicated upon the fact that the identical similarity of the business conducted by American Express Company ... and that in which plaintiffs intend to engage and which on its face the Act says must be regulated by the state, is an arbitrary discrimination." 'r27 F. Supp. at 855 . See note 28 infra.

${ }^{10}$ In $A . F$. of L. 0 . Watson, 327 U.S. 582,596 (1946), where it was alleged that a state constitutional amendment outlawing "closed union shops" violated the Federal Constitution, the Supreme Court affirmed the district court's abstention, and said: "When authoritatively construed, it may or may not have the meaning or force which appellees now assume that it has. In absence of an authoritative interpretation, it is impossible to know with certainty what constitutional issues will finally emerge. What would now be written on the constitutional questions might therefore turn out to be an academic and needless dissertation." See also, Spector Motor Services, Inc. v. McLaughlin, 323 U.S. ror (1944); Chicago v. Fieldcrest Dairies, 3 I6 U.S. 168 (1942); Railroad Commission of Texas v. Pullman Co., 312 U.S. 496 (194I). Cf. Propper v. Clark, 337 U.S. 472 (1949); Meredith v. Winter Haven, 320 U.S. 228 (1943).

${ }^{20}$ If a district court assumes jurisdiction and construes a state statute in the first instance, two possible results might follow. If the constitutionality of the statute is 
can adequately support abstention by a three-judge district court only when there exists a substantial probability that a constitutional construction will be put upon the statute by a state court; and unless it is demonstrable that a restrictive interpretation is open to the state courts, such a substantial probability cannot exist. ${ }^{21}$ This is not to imply that the federal courts should undertake an express demonstration of the alternative constructions which could save the state statute; for to do so might carry the implication that the district court was announcing a provisional decision on the constitutional question. Nevertheless, the district court should balance the probabilities and abstain only when there is a general sentiment that the constitutional issue will be averted in the state courts.

To the extent that there is abstention in a case where no substantial probability of averting the constitutional issue exists, the federal court is obviously being prompted by something other than the anticipation of a restrictive state court treatment. Abstention in such a case must actually be grounded, instead, in the principles of comity and convenience, ${ }^{22}$ which, on the one hand, could impel a federal court to abstain for no other reason than that the state statute had not been construed by the state courts. Some recent Supreme Court cases, in fact, seem to justify their abstention merely on the absence of a state court construction, rather than on the substantial probability of a narrow construction. ${ }^{23}$

upheld through a narrow district court construction, a state court might subsequently render a broad interpretation, and thereby necessitate further constitutional adjudication. On the other hand, the district court might declare the statute unconstitutional, only to have a state court circumvent that decision by a narrower construction of the statute. See the opinion of Mr. Justice Frankfurter in Railroad Commission of Texas v. Pullman Co., 312 U.S. 496, 500 (1941): "The resources of equity are equal to an adjustment that will avoid the waste of a tentative decision as well as the friction of a premature constitutional adjudication."

${ }^{21}$ In Public Utilities Commission of Ohio ø. Onited Fuel Gas Co., $3 \times 7$ U.S. 456 (1943), the Supreme Court affirmed a district court decree enjoining enforcement of a state commission's orders fixing gas rates to be charged for natural gas transported in interstate commerce. As to the possibility of abstaining to await a narrow state court construction of local law, the Court said at p. 463 : "But where ... no state court ruling on local law could settle the federal questions that necessarily remain ... considerations of equity require that the litigation be brought to an end as quickly as possible."

${ }_{22}^{2}$ See Franlfurter, Distribution of Judicial Power Between United States and State Courts, ${ }_{3}$ Connelr L.Q. 499, 519-520 (1928). Query, whether the last phrase of the language of Mr. Justice Frankfurter, quoted in note 20 supra, if read out of the context of his opinion, could support an argument that comity alone can form the basis of equitable abstention.

${ }^{23}$ In Albertson ข. Millard, 345 U.S. 242 (1953), the district court had declared the state statute constitutional. The Supreme Court vacated that decision and ordered the lower court to hold the bill pending an authoritative interpretation in the state courts. 
On the other hand, principles of comity could also impel a federal court to abstain until the state court passes upon the constitutional issue. Illustrative of this approach, perhaps, is Stainback v. Mo Hock Ke Lok $\mathrm{Po}^{24}$ where the Supreme Court seems to rest its affirmance of the lower court's abstention, at least in part, ${ }^{25}$ on the premise that state courts are the natural tribunals to determine the constitutionality of state statutes. ${ }^{20}$ Though the Stainback opinion may have manifested some expectation that the state court would decide the constitutional issue, ${ }^{27}$ in no case has

In a per curiam opinion, the Court said at p. 244: "Interpretation of state legislation is primarily the function of state authorities, judicial and administrative. . . . There has been no interpretation of this statute by the state courts." Similarly, in a per curiam opinion in Shipman v. DuPre, 339 U.S. 32x, 322 (1950), the Court said: "From the papers submitted on appeal, it does not appear that the statutory sections in question have as yet been construed by the state courts. We are therefore of opinion that the District Court erred in disposing of the complaint on the merits." [citing A.F. of L. v. Watson, 327 U.S. 582, 595-599 (1946)]. See Alabama Public Service Commission v. Southern Ry. Co., 34 I U.S. 34 I (I95I). Cf. Rescue Army v. Municipal Court, 331 U.S. 549, 584 (1947): "[J] urisdiction ... should be exerted only when the jurisdicdictional question presented ... tenders the underlying constitutional issues in clean-cut and concrete form, unclouded by any serious problem of construction relating either to the terms of the questioned legislation or to its interpretation in the state courts." See note 22 supra.

${ }^{24} 336$ U.S. 368 (1949). The action was initiated in the federal district court in Hawaii to enjoin the enforcement of a territorial act restricting the teaching of foreign languages and the persons allowed to teach them in territorial schools. On appeal, the Supreme Court remanded the cause to the district court with directions to dismiss the complaint.

${ }^{25}$ The opinion did not expressly rely on the possibility that construction of the statute by the territorial courts might avert the federal constitutional questions. But some reliance does seem to have been placed on the fact that there had been no local construction of the statute: "The complaint called for broad consideration of the application of the Act to foreign language schools and teachers. It had not been construed by the Hawaiian courts." 336 U.S. 383 .

${ }^{26}$ "[E]ntirely aside from the question of the propriety of an injunction in any court, territorial like state courts are the natural sources for the interpretation of the acts of their legislatures and equally of the propriety of interference by injunction. We think that where equitable interference with state and territorial acts is sought in federal courts, judicial consideration of the acts of importance primarily to the people of a state or territory should as a matter of discretion, be left by the federal courts to the courts of the legislating authority unless exceptional circumstances command a different course." 336 U.S. at 383 . See, Note, 28 TeXas L. REv. 4 Io (1950).

${ }^{27}$ Conceivably, the Court might have abstained on the premise that the issue was not yet ripe for decision. The only means available for enforcement of the statute was by injunction in the territorial courts. Cf. A.F. of L. v. Watson, 327 U.S. 582,598 (1946), where the Court said: "[I]f . . . this Florida law is not self-executing, suits seeking to raise the due process question or any other constitutional questions would be premature until Florida supplied sanctions for its enforcement. A decision today on the merits might, therefore, amount to no more than an advisory opinion." See, Davis, 
the Supreme Court announced this expectation as the basis of its decision in as categorical terms as did the district court in Doud v. Hodge. The statute there had been once construed by the state court in a case similar to the present; ${ }^{28}$ yet the three-judge court held that: $:^{29}$

The federal courts, before passing on the question urged by the present plaintiffs [i.e., the constitutional issue], must wait until the Illinois Supreme Court has spoken in answer to that same question. [Emphasis added.]

The effect of abstaining solely on principles of comity should be fully appreciated. Since any one of the three possible results of state litigation will render further resort to a three-judge district court unlikely, when the court abstains, it forever surrenders its opportunity of passing on the constitutional issue. Therefore, if the doctrine of equitable abstention is not to be confined to those cases in which state court construction may validate the statute, but rather is to be extended to all cases in which the state court either has not construed the statute or has not passed on the narrow constitutional question, the result will be a judicial elimination of the federal district court as a testing ground for the constitutionality of state legislation. In spite of strong opposition by those who believe that constitutional rights may be adequately safeguarded through $\mathrm{Su}$ preme Court review of the highest state court decisions, Congress has refused to abolish the jurisdiction of three-judge district courts. ${ }^{30}$ Whether the Supreme Court should contravene that legislative intent purely in deference to the sensitivity of federal-state relations may be doubtful. Doud v. Fodge offers the Court an opportunity to make that choice.

Geraid B. TJoflat

Ripeness of Governmental Action for Judicial Review, 68 HARv. L. Rev. I122, I I39 and 1326 (1955).

${ }^{28}$ McDougall v. Lueder, 389 IIl. I41, 58 N.E.2d 899 (I945).

20127 F. Supp. at 856 .

${ }^{30}$ In his concurring opinion in Alabama Public Service Commission v. Southern Ry., 34I U.S. 34I (195I), Mr. Justice Frankfurter said, at pp. 358-359: "Plainly we are concerned with a jurisdictional issue which has been continuously before Congress and with which it has dealt by explicit and detailed legislation. . . . But Congress did not take away the power of the district court to decide a case like the one before us. Instead, it recognized . . . that such power was an obligatory jurisdiction, not to be denied because as a matter of policy it might be more desirable to raise such constitutional claims in a state court. ..." 